\title{
ОБЩАЯ ХАРАКТЕРИСТИКА ГРИБОВ, РАСПРОСТРАНЕННЫХ НА ЗАСОЛЕННЫХ ПОЧВАХ
}

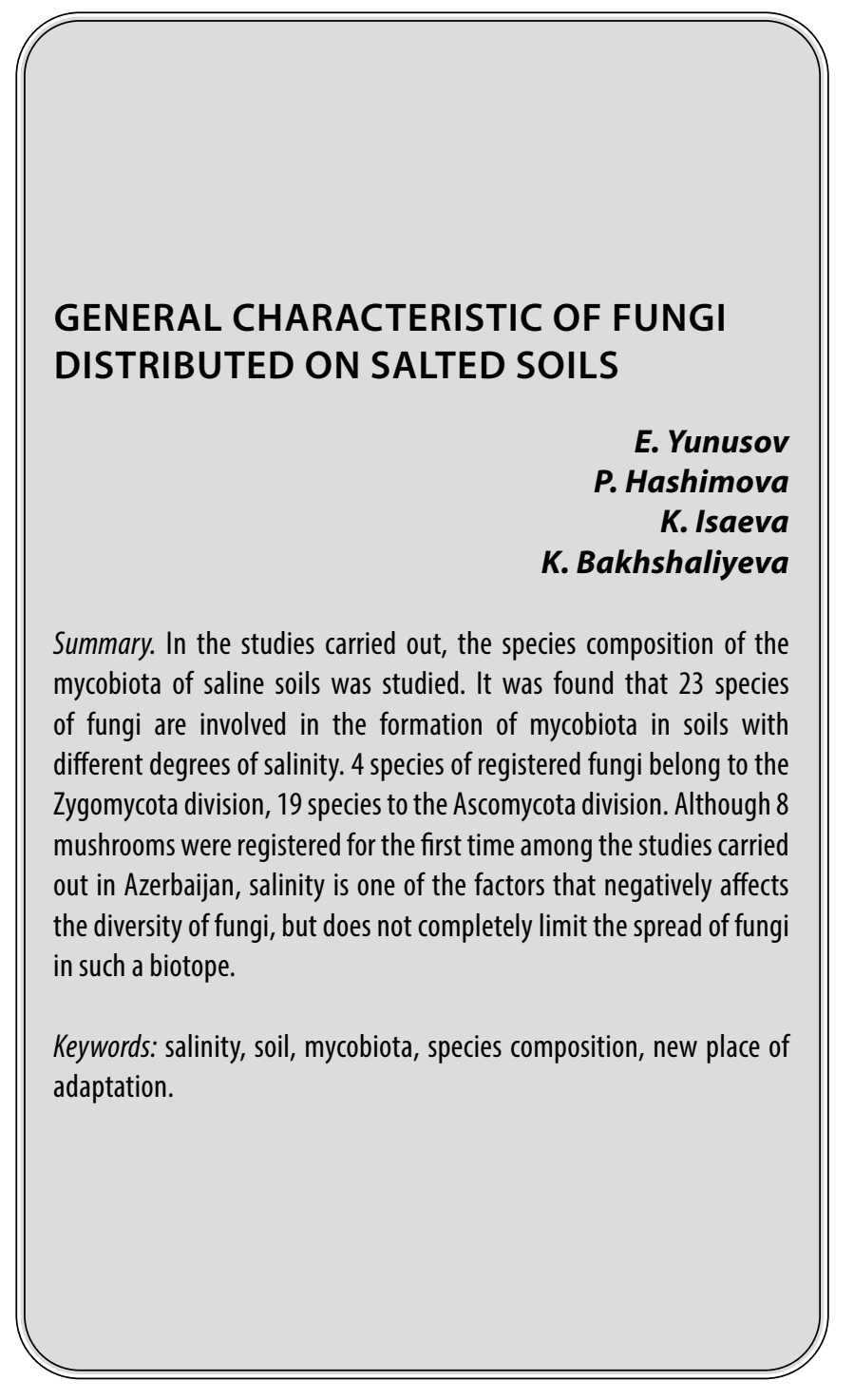

\section{Введение}

и звестно, что грибы являются одним из постоянных компонентов гетеротрофного блока любой экосистемы, включающей органическое вещество и активными участниками процессов продукции, разрушения, индикации и регуляции, которые происходят в этой экосистеме [14]. Точнее, они выполняют важные и незаменимые экологические функции как активные участники всех процессов, происходящих в экосистеме. По этой причине грибы необходимо учитывать при оценке процессов, происходящих в любой экосистеме.
Юнусов Эльшад Рустам оглы

Диссертант, Институт Микробиологии НАН

Азербайджана, г. Баку

elsadyunuslu@gmail.com

Хаиимова Парвин Мирдамат гызы

Диссертант, Институт Микробиологии НАН

Азербайджана, г. Баку

peri.omar87@gmail.com

Исаева Камала Камаладдин гызы

Д.фрилософии по биологии, старший преподаватель, Сумгаитский Государственный Университет, Азербайджан, г. Сумгаит kamalaisayeva@gmail.com

Бахшалиева Конул Фаррух гызы Д.б.н., Институт Микробиологии НАН

Азербайджана, г. Баку

konul.baxsh@mail.ru

Аннотация. В проведенных исследованиях изучен видовой состав микобиоты засоленных почв. Установлено, что в формировании микобиоты в почвах с разной степенью засоления участвуют 23 вида грибов. 4 вида зарегистрированных грибов принадлежат к отделу Zygomycota, 19 видов к отделу Ascomycota. Хотя 8 грибов зарегистрированы впервые среди исследований, проводимых в Азербайджане, засоление является одним из факторов, негативно влияющих на разнообразие грибов, но не ограничивает полностью распространение грибов в таком биотопе.

Ключевые слова: засоление, почва, микобиота, видовой состав, новое место адаптации.

Учитывая резкое увеличение антропогенной нагрузки на окружающую среду в последнее время, следует отметить, что антропогенные воздействия в любом случае вызывают изменения характера и направленности протекающих в природе природных процессов, что в большинстве случаях носит негативный характер [13.]. Чтобы предотвратить или контролировать это, необходимо четко идентифицировать участников процессов, которые приводят к этим изменениям. В отличие от макроорганизмов изучение микроорганизмов сопряжено с определенными методическими трудностями (например, непосредственное изучение их в местах обитания, ввиду их малых, невидимых невооруженным 
глазом размеров). По этой причине микроорганизмы, присущие экосистемам, по-прежнему сохраняют свою актуальность для исследований.

Несмотря на то, что Азербайджанская Республика обладает богатой и разнообразной природой [9], на ее территории проводятся широкомасштабные производственные процессы различного характера, в результате чего в стране почти не встречаются экосистемы, полностью сохранившие свою природность, и это ярко выражено на Абшеронском полуострове. Так, сегодня Апшеронский полуостров характеризуется как критический ареал с геологическими и экологическими проблемами [1], и поэтому изучение микроорганизмов в этой зоне можно отметить как предмет особого внимания.

Помимо нефтезагрязненных почв на Абшеронском полуострове имеются территории, подверженные и другим воздействиям. Одни из них - почвы вокруг озера Масазыр, расположенного на Абшеронском полуострове. В то же время нет сомнений в том, что почвы вокруг этого озера, известного как «соленое озеро», подвержены засолению [5]. Выявление живых организмов, обитающих в таких условиях, и использование их для предотвращения этой ситуации представляет, как научный, так и практический интерес. Так, засоление наряду с засухой считается сейчас одним из серьезных факторов, ведущих к снижению урожайности.

Тенденция увеличения площади почв, подверженных таким воздействиям, определяет важность обращения должного внимания к данной проблеме. Для устранения данной проблемы, восстановления почв, подверженных различным воздействиям, используются различные подходы, одним из которых является использование организмов, обитающих в почвах данного типа, в первую очередь, микроорганизмов[18]. Почвенные микроорганизмы - это в основном бактерии, актиномицеты, микроскопические грибы и почвенные беспозвоночные [16], которые различаются по своему количеству, функциям и обогащению почвы своей биомассой и метаболитами [3, 11-12]. Среди них грибы имеют особое значение, и тому есть ряд причин, из которых уместно упомянуть следующие.

Во-первых, почва является одним из наиболее населенных грибами мест [19], где они участвуют во всех происходящих процессах[21]. Обогащение окружающей среды теми или иными веществами приводит к нарушению их функций, что приводит к изменению биологической активности почв, в первую очередь, плодородия. Выявление грибов, приспособленных к жизни в таких условиях и повышающих плодородие почвы, важна с точки зрения их будущего использования для восстановления такого рода почв.
Во-вторых, усиление антропогенного и техногенного воздействия на окружающую среду приводит к увеличению опустыниванию, засолению, глобальному изменению климата и других негативных явлений, а территория таких почв постепенно расширяется. Поэтому для устранения данной проблемы изучение грибной биоты ценозов с экстремальными условиями представляет, как научный, так и практический интерес.

По этой причине целью представленной работы была оценка видового состава грибной биоты засоленных почв Апшеронского полуострова (на примере почв вокруг озера Масазыр)

\section{Материалы и метолы}

Как было отмечено ранее, исследование почв проводились вокруг озера Масазыр, расположенное на Абшеронском полуострове. Озеро находится в 21 км от Баку, то есть в поселке Масазыр Абшеронского района и занимает площадь 10 км². Длина береговой линии составляет 14 км, а соленость - 33 промилле (> 200 $\mathrm{mS} / \mathrm{s})$. Питается озеро, в основном, грунтовыми водами, формируемых за счет осадков. Кроме того, в озеро сбрасывается коммунальные воды из поселков Масазыр и Новханы. Северный, южный и западный берега озера составляют песчаные, гравийные и глинистые, а восточные берега - в основном, глинистые почвы. Озеро Масазыр по минерализации воды относится к группе соленых озер. В ионном составе воды преобладают хлориды и сульфаты[2].

Условно разделяя озеро Масазыр на северо-восточное, северо-западное, юго-восточное и юго-западное направления, вдоль береговой линии на расстоянии 2-3 км от озера с интервалом 100-200 м были пробурены скважины глубиной 50-80 см и по диагонали с определенной глубины (поверхность, 10 см, 20 см, 40 см, 60 см, 80 см) были взяты образцы почв. Отбор, упаковка и лабораторный анализ образцов почв проводились в соответствии с методами и подходами, используемыми в настоящее время в микологической работе [4, 6-8]. Для получения чистой культуры грибов использовали стандартные питательные среды (агаризованное солодовое сусло, агар Сабуро, картофельный агар, агаризованный Чапек). Чистоту культуры контролировали методами микроскопического исследования.

Идентификация грибов, полученных из чистой культуры, проводилась в соответствии определителями, составленными на основе культурально-морфологических и физиологических признаков $[10,17,20]$, а присвоение наименований грибам осуществлялось в соответствии с применяемыми в настоящее время международными принципами[15]. 
Таблица 1. Распределение зарегистрированных в исследовании грибов по отдельным таксонам

\begin{tabular}{|l|l|l|l|l|}
\hline Отдел & Класс & Порядок & Семейство & Род (вид) \\
\hline Zygomycota & 1 & 1 & 1 & $2(4)$ \\
\hline Ascomycota & 4 & 4 & 6 & $8(19)$ \\
\hline
\end{tabular}

\section{Полученные результаты} и их обсужАение

В проведенных с 2016 года исследованиях было взято более 200 образцов почв вокруг озера Масазыр и изучена главным образом их грибная биота. В результате было получено около 300 чистых культур. Определение видового состава полученных чистых культур показало, что они принадлежали к 23 видам, а информация об их распределении по более крупным таксонам представлена в таблице 1. Как видно, большинство зарегистрированных грибов (общих грибов) относятся к сумчатым грибам и небольшая часть - к зигомицетам.

Среди зарегистрированных родов по количеству видов преобладал род Aspergillus и 7 видов грибов, зарегистрированных в исследованиях (A.arenarioides, A.flavus, A.niger, A.ochraseus, A.terreus, A. transcorpathicus и A. .versicolor).) приходится на этот род. Род Penicillium представлен 5 видами (P.citrinum, P.glabrum, P.resticulosum, P. roseopurpureum и P.subericola), Fusarium - 2 видами (F. equiseti и F. xylarioides), Mucor - 2 видами (M. himelais и M.musedo), 2 вида из рода Paecilomycetes (P.lilacinus и P.farinosus) и 2 вида из рода Rhizobus (Rh.nigricans, Rh.), что в общей сложности составляет 20 видов. Остальные 3 вида составляют грибы Curvularia prasadii R.L. Mathur \& B.L. Mathur, Tritirachium album Limber и Cladosporium cladosporioides (Fresen.) G.A. de Vries.

Следует отметить, что сравнение полученных результатов с грибами, зарегистрированными в других экосистемах, а также с грибами, находящимися в состоянии стресса (например, в нефтезагрязненных почвах), позволяет рассматривать микобиоту засоленных почв как обедненную, что еще раз дает возможность рассматривать экстремальные условия как фактор, снижающий количество видов. Точнее, к таким факторам можно отнести и засоление.

Некоторые из зарегистрированных в исследовании грибов обнаружены также в других исследованиях, проведенных в Азербайджане, среди которых можно отметить A. flavus, A. niger, A. ochraseus, A. terreus, $M$. himelais, M. mucedo и P.citrinum, являющиеся широкораспространеными видами присущей для Азербайд- жана микобиоты. Частота встречаемости этих грибов в образцах почвы колеблется от 1,5\% до 56,8\%. Однако отсутствуют литературные данные о распространении некоторых из зарегистрированных грибов в микологических исследованиях в Азербайджане, т.е. в Азербайджане они зарегистрированы впервые. К ним относятся следующие виды:

1. Aspergillus arenarioides Visagie, Hirooka \& Samson, Studies in Mycology 78: 110 (2014) [MB\#809195].

2. A.transcarpathicus A.J.Chen, Frisvad \& Samson, Studies in Mycology 85: 83 (2016) [MB\#817727].

3. Curvularia prasadii R.L. Mathur \& B.L. Mathur, Current Science 28 (11): 449 (1959) [MB\#296253].

4. Fusarium equiseti (Corda) Sacc., Sylloge Fungorum 4: 707 (1886) [MB\#199819].

5. F. xylarioides Steyaert, Bulletin de la Société Royale de Botanique de Belgique 80 (1-2): 42 (1948) [MB\#286515].

6. Penicillium lilacinus (Thom) Samson, Studies in Mycology 6: 58 (1974) [MB\#319114].

7. P.farinosus (Holmsk.) A.H.S. Br. \& G. Sm., Transactions of the British Mycological Society 40 (1): 50 (1957) [MB\#302185]

8. Tritirachium album Limber, Mycologia 32: 27 (1940) [MB\#291611].

Выделение за исследуемый период 8 видов, новых не только для территории, но и для Азербайджана, позволяет отметить с одной стороны, что микобиота, присущая природе Азербайджана, до сих пор всесторонне не изучена, а с другой стороны, что в формировании микобиоты почв стрессовых условий участвуют специфические виды. Точнее, в биотопе под воздействием одного и того же стрессового фактора в течение длительного времени отдельные виды приспосабливаются к среде обитания, и выявление механизма данного явления имеет большое научное и практическое значение, выяснение которого является предметом дальнейших исследований.

Таким образом, хотя микобиота, сформированная в засоленном биотопе, считается обедненной по видовому составу, такие территории не сильно препятствуют распространению специфических видов грибов и характеризуется как одно из местообитаний грибов. 


\section{ЛИТЕРАТУРА}

1. Алекперов А.Б. Апшерон: проблемы гидрогеологии и геоэкологии. Баку, 2000, 484с.

2. Гасанов, М., Заманов, Х., Джафаров, Б., Велиев, Н. Реки, озера и водные бассейны Азербайджана. Баку, 1973, с. 111-112

3. Звягинцев Д.Г., Бабьева И.П., Зенова Г.М. Биология почв. М.: Издательство МГУ, 2005, 445 с.

4. Зенова Г.М., Степанов А.Л., Лихачева А.А., Манучарова Н.А. Практикум по биологии почв.— М.: Издательство МГУ, 2002,120 с.

5. Мамедов, В. А., Халилова, Х.Х. Пути трансформации соледобычи из самосадочных озер Апшеронского полуострова//Записки горного института, 2016, т. 222, с. 809-815

6. Методы почвенной микробиологии и биохимии. /Под ред. Звягинцева Д.Г. М.: МГУ, 1991, 302с.

7. Методы экспериментальной микологии/Под. ред. Билай В.И. Киев: Наукова думка, 1982, 500с.

8. Нетрусов А.И., Егорова М.А., Захарчук Л.М. и др. Практикум по микробиологии. М.: Издательский центр «Академия», 2005, 608с.

9. Общая информация о природе Азербайджана// https://files.preslib.az/projects/azereco/ru/eco_m1_1.pdf

10. Саттон, Д. Определитель патогенных и условно патогенных грибов / Саттон Д., Фотергилл А., Риналди М., — Москва: Мир, — 2001, — 486c.

11. Anderson T.-H., Domschc K.H. Soil microbial biomass: The eco-physiological approach // Soil Biology and Biochemistry, 2010, v.42, p.2039-2043.

12. Bardgett R.D. The biology of soil. A Community and Ecosystem Approach. Oxford, 2005, 901p.

13. Correia, A.W., Pope, C.A., Dockery, D.W. et al. The Effect of Air Pollution Control on Life Expectancy in the United States: An Analysis of 545 US counties for the period 2000 to 2007.// Epidemiology, 2013, v.24, p.23-31.

14. Hyde, K.D., Xu, J., Rapior, S. et al. The amazing potential of fungi: 50 ways we can exploit fungi industrially.//Fungal Diversity, 2019, v.97, p.1-136.

15. http://www.mycobank.org/MycoTaxo.aspx

16. Microorganisms found in soil with effects and examples, 2020/ https://microbenotes.com/microorganisms-in-soil/

17. Samson, R.A. Integration of modern taxonomic methods for Penicillium and Aspergillus classification / R.A. Samson, J.I. Pitt; — Amsterdam: Harwood Publishers, - 2000,-510p.

18. Shrivastava, P., Kumar, R. Soil salinity: A serious environmental issue and plant growth promoting bacteria as one of the tools for its alleviation.//Saudi J Biol Sci., 2015, 22(2), p.123-131

19. Sun, J. M., Irzykowski, W., Jędryczka, M., and Han, F.X. Analysis of the genetic structure of Sclerotinia sclerotiorum (Lib.) de Bary populations from different regions and host plants by Random Amplified Polymorphic DNA markers.// J. Integr. Plant Biol., 2005, v.47, p.385-395

20. Subramanian C.V. Hyphomycetes/ New Delhi: Icar, 1971, 930p.

21. Zifcakova, L., Vetrovsky, T., Howe, A., and Baldrian, P. Microbial activity in forest soil reflects the changes in ecosystem properties between summer and winter. Environ. Microbiol., 2016, v.18, p.288-301 